\title{
Managing the Risks in the Clothing Supply Chain Considering the Coronavirus Pandemic
}

\author{
Eli Sumarliah \\ School of Economics and Management \\ University of Science and Technology Beijing, China \\ E-mail: 2761514566@qq.com (Corresponding Author) \\ Kamila Usmanova \\ School of Economics and Management \\ University of Science and Technology Beijing, China \\ E-mail: kami886@mail.ru \\ Fauziyah Fauziyah \\ School of Computer and Communication Engineering \\ University of Science and Technology Beijing, China \\ E-mail: b20190694@xs.edu.cn \\ Kawther Mousa \\ School of Economics and Management \\ University of Science and Technology Beijing, China \\ E-mail: b20200713@xs.ustb.edu.cn
}

\begin{abstract}
This paper examines the systemic and complex influences of the $\mathbf{2 0 2 0}$ Coronavirus epidemic on the supply chains (SCs) of international clothing companies through a global business risk management perspective. The Coronavirus pandemic has triggered supply and demand disturbance risks that strongly affect supply chain (SC) management, signifying a necessity to develop the agility to alleviate such risks. This study revealed that the lean-SC management model is inadequate due to the dearth of transparency in the SCs caused by the growing demand uncertainty detected even before the Coronavirus pandemic. Although agile-SC management copes with this issue by improving the purchaser-supplier relations and communication to enhance information exchange, this model also requires a related rise in business stock and inventory costs. Hence, the paper provides several strategies that companies can implement to manage the risks and identify main fields for future studies, including the parties in the clothing SCs both downstream and upstream.
\end{abstract}

Keywords: clothing industry, supply chain management, risk management, Coronavirus, COVID-19

\section{INTRODUCTION}

After the Second World War and post-war economic industrialization, speedy globalization caused companies to expand their clothing manufacturing to emerging economies to gain cost-effectiveness via foreign direct investment, alliances, and outsourcing. The growing customers' demands for low prices and broad choices in the mass market sector has triggered higher competition and lower revenue, causing the relocation of the supply chain (SC) operations from nations with higher-cost inputs to countries with lower-cost resources in Africa, Asia, and Europe (Graafland, 2002). The motivations for this global subcontracting involve business expansion, sourcing (i.e., material and talent), and proximity to sales locations (Caniato et al., 2015); however, costeffectiveness is often perceived as the central stimulus for large companies to adopt global outsourcing (Di Gregorio et al., 2009).

Since the international SC implementation, the clothing business has been contemplated regarding its dynamism, unpredictability, rapidity, variability, intricacy, and SCs in the clothing segment are filled with volatility and uncertainty (Mustafid and Jie, 2018). Sumarliah (2021) reported that demand unpredictability, the less-advanced design models, and the swiftly changing clothing trend, are among the most critical risks in the global clothing SC. Similarly, Sumarliah et al. (2021a) found that the vital risks in the global fashion $\mathrm{SC}$ include customer need diversity, demand fluctuation, the fast-changing fashion trends, and the less developed design concept. Martino et al. (2015) reveal that international clothing companies have faced critical risks that have mostly been recognized, e.g., delayed distributions, lengthy waiting between return and resending to customers, out of stock, excess stock, and single-solution distributions. Besides, the SC globalization has caused clothing companies to face country-exclusive risk, causing regional high-risk factors to escalate on a large scale (Bevilacqua et al. 2019a). Because of the Coronavirus, amidst a pandemic with nations having different techniques and capacities to control the coronavirus, lockdown, and social distancing policies that 
restrict manufacture in major supplier markets disclose the limitations of the current SC management styles.

As the Coronavirus pandemic has driven the transition to a more responsive supply chain, the discussion of this paper on the advantages and disadvantages of lean-SC versus agile-SC management will provide new insights for the present studies, which are unsuccessful in providing significant thought to the long-run structural transformation that will be succeeded after the pandemic. Part 2 of this paper systematically evaluates and develops SC risk management subjects related to the Coronavirus pandemic and summarizes the literature supporting the most recent SC management. Part 3 looks at the lean and flexible SC management models' strengths and weaknesses before examining the risks emphasized and mapped during the pandemic. According to the background and literature review, Part 4 presents the Coronavirus's implications for managing SC risks. Part 5 discusses boundary issues, and Part 6 presents the conclusion.

\section{BACKGROUND AND LITERATURE REVIEW}

\subsection{Coronavirus Background}

On March 11, 2020, the highly-contagious Coronavirus was announced by the World Health Organization as a worldwide pandemic (Armani et al., 2020). While its precise sources are unidentified, the Coronavirus epidemic is supposed to have arisen in Wuhan, China, at the end of 2019. The Coronavirus's gravity varies among persons, starting from minor indications of coughing, fever, and breath brevity to critical respirational issues in severe incidents. Zhou et al. (2020b) report that a significant quantity of cases has caused medical treatment and even death. On August 22, the Coronavirus had infected more than 211 million people globally, and the death number was more than 4.4 million (WHO, 2021).

The global epidemic has immensely disturbed supply chains at the local and global scale (Pujawan \& Bah, 2021). It has disrupted many companies' operations and affected supply and demand (Ivanov, 2020). The pandemic's novel characteristics have signified that industries had no earlier preparation and were subjected to critical risks. Research directed by Ernst and Young revealed that among 500 chief executive officers worldwide, only twenty percent of the CEOs had confidence that their companies were ready to take action on significant disadvantageous risks (Ernst and Young, 2020). Although most of Coronavirus's short-run or medium-run effects can be detected at this time, the long-run effects are still unclear. The pandemic has destroyed numerous worldwide supply chains (Araz et al. 2020), especially for corporations with lean and internationalized SC systems. Over 90 percent of the Fortune-1000 companies have gone through Coronavirus's SC disturbances (Sherman, 2020). Therefore, companies have been urged to undertake significant efforts to restructure SCs, increase flexibility, and reevaluate relations with supply partners to alleviate widespread risks.

\subsection{Supply Chains in the Clothing Business}

The usual clothing supply chain (SC) schema includes sourcing, warehousing, logistics (inbound and outbound), manufacturing, packaging, selling, and closes with consumer service (Sumarliah et al., 2020; Sumarliah et al., 2021b). SC management synchronizes manufacturing, selection, setting, and shipping along the SC to attain the greatest mixture of efficacy and receptiveness for the market handled. The objectives of an SC are to minimize costs in the entire scheme, expand the over-all sales volume, and satisfy consumers' needs (Sumarliah et al., 2021b).

The SCs' elements and characteristics in the clothing business vary from company to company, depending on aspects such as commodities, consumer types, competitive preferences, international strategies, supplier incorporations, delivery postponements, and lead times (Fisher, 1997; Kim 2013; Lee, 2002; Mehrjoo and Pasek, 2016). The SC management studies have created much research examining the various models of SC management for clothing companies. The clothing business, especially the fast-fashion industry, is distinguished by seasonality, high buying impulsivity, demand instability, and unpredictability (Martino et al., 2015; Mehrjoo and Pasek, 2016). SC management strategies vary between the clothing companies since the elements of SCs differ within the industry. Different SC management approaches in increasing effectiveness and alleviating risks have been examined in many SC studies.

Kim (2013) interviewed big firms' CEOs to identify determinants influencing SC management strategies; the conclusion is that firms' competitive preferences have a significant relationship with their target market selection, affecting firms' selection of SC strategies. Notable research on SC conducted by Fisher (1997) reveals that the best SC management strategies depend on its product characteristics. Fisher (1997) emphasizes two types of goods: (1) valuable goods, which need to be combined with physically useful SC, and (2) inventive goods, which need to be combined with a reactive market approach. As an alternative, Lee (2002) classifies the commodities based on their demand/order stability. Commodities with steady order must be handled differently from products with unstable demand. Companies should strongly emphasize synchronizing their strategies with the supply and demand instabilities if a commodity has volatile demand.

Shen and Chen (2019) argue that companies operating in the clothing business typically face the double challenges of upholding low costs and short lead-times. It has caused the creation of a geographically complicated and purchaserdriven subcontracted SCs. Mehrjoo and Pasek (2016) confirm that the lead time impact on SCs operation (i.e., cost, inventory, risk, backlog) is the solution to achievement in the fast-fashion segments. The best SC strategies to deal with those challenges must focus on building relations with the subcontracted clothing SC (Shin and Chen, 2019). Likewise, the incorporation of suppliers can powerfully improve economic performance and alleviate a monetary disaster's adverse impact on clothing companies' financial execution (Martino et al., 2015). Even though Martino et al. (2015) highlight the significance of relations with suppliers, it is inadequate because it does not contemplate the significance of flexible SCs. Reliance on a few suppliers may increase the risk of SC disturbance in unforeseen situations, as detected with the worldwide Coronavirus outbreak. However, the clothing business tends to reduce operational expenditures, and companies often implement flexibility to attain a lean 
SC. The critical issues in the clothing SCs are market instability and dynamism (Choi, 2007; Gligor et al., 2006) and the high unpredictability of customer demands (Choi, 2007); that may trigger overstocking or understocking issues (Choi 2006, 2007). The following section describes the significance of flexible SC.

\subsection{Supply Chain Disturbance Risk and Alleviation Tactics}

The main determinants affecting SC disturbances and the best methods for corporates to reduce the related risks have been investigated in the latest SC research. Firstly, the resolution to choose a simple $\mathrm{SC}$ system or a complex $\mathrm{SC}$ system has been argued. Compared to a simpler SC, the complex system tends to be more sensitive to acute disturbances, where restraint in one SC element can affect the system's following SC elements (Ivanov and Dolgui, 2019). The effect of unforeseen occurrences and how severely it could impact SC has also been examined. Ivanov (2020) employs a simulation method to analyze the effects of the Coronavirus on international SCs, observing its effect on determinants important to SC operations such as facility opening and closing times, lead time, and the swiftness of pandemic spread and the duration of upstream and downstream disruptions.

Concerning alleviating the risk of SC disturbances, research shows that flexibility and diversification are the optimal methods to evade such risk. By studying the impact of determinants influencing SC resilience in the clothing business, Bevilacqua et al. (2019b) propose that agile manufacturing systems are essential to successfully cope with unexpected market changes in a timely fashion, as producers emphasize flexibility in meeting demands.

Similarly, in the study notes about Coronavirus and SC resilience, Ivanov and Das (2020) confirm that SC-resilience management's emphasis needs to change situational reactions to actual-time shifts. In improbable but acute situations of SC disturbances, impermanent sourcing diversification can be a successful reaction approach. Lastly, it has been proved that the flexibility of procurement, production, and delivery mediates the link between ecological unpredictability and SC risks (Sreedevi and Saranga, 2017).

Regarding a suitable SC system, which indicates the SC system's adjustment and flexibility, critical disturbances can alter the SC system and engage with the SC's structural dynamics (Ivanov and Dolgui 2019, 2020). A technique that helps firms improve the assessment of the unseen chain reaction and the effect of an exclusive stimulus event and estimate the extent to which they can disturb SCs is suggested by Bevilacqua et al. (2019b). This kind of framework is beneficial for companies' decision-making regarding SC systems. Driven by the Coronavirus epidemic, Ivanov and Dolgui (2020) suggest the viability and reliability of intertwined supply networks (ISN). Ivanov and Das (2020) and Ivanov and Dolgui (2020) define ISN as a whole extent of interrelated SCs that fortify the product and service supply to the markets and customers, whereas SC-viability management will alternatively be shifted towards the circumstanced responses.

The problems that SC management suffers from is the ripple effect and bullwhip effect. Based on Bevilacqua et al. (2019b), the ripple effect happens when a disturbance causes a sequence effect up the chain and down the chain that affects SC operation. On the other hand, according to Snyder and Shen (2019), the bullwhip effect discloses inaccurate information among individuals in the SC, escalating the management cost, product supply and storage cost, and lead times. To lessen the ripple effect, Ivanov et al. (2018) investigate Industry 4.0 and digital technology's functions in increasing demand sensitivity and ability flexibility. Ivanov et al. (2018) report that with supports from the technology of Tracking and Tracing System and Big Data Analytics, Industry 4.0 strengthens the capability to rearrange capital/resources in the recovery phase. The bullwhip effect problem is deepened when the buying behaviors are unpredictable and not efficiently conveyed from the selling point to the supply point. Sarkar and Kumar (2015) discover the risk alleviation tactic of distributing actual-time information about SC risks between producers and sellers. This approach minimalizes the effect of disturbances by making adjustments to inventory decisions to prevent understocking or over-stocking, lessening the bullwhip effect and its related expenses.

The literature review on SC management delivers a comprehension of the determinants contributing to SC models' selection. The issue of which $\mathrm{SC}$ system has the highest effectiveness at alleviating the risk of SC disturbances has been discussed extensively and gives space for future examination of the advantages of a lean-SC system compared to a more diversified and agile SC system.

\section{SUPPLY CHAIN MANAGEMENT MODELS AND RELEVANCES}

Based on Lee (2002), companies' SC approaches to increase their operative effectiveness regarding their target market consist of four general types: (i) cost-effectiveness, (ii) risk alleviation by sharing and merging capital/resources to minimize the effects of disturbances, (iii) flexibility and sensitivity to transformation, and (iv) agility that needs a fast and active reaction to customers' demand instabilities while lessening SC disturbances. Mehrjoo and Pasek (2016) suggest that the clothing business strategies include brand equity, rapidity, and cost advantages. While those tactics are necessary for all clothing sectors, high-end brands frequently pay massive attention to the high quality of materials and products, design, and style to increase brand equity. Robinson and Hsieh (2016) reveal that those luxury brands improve their product quality by applying a vertically incorporated SC with most production and procurement processes finalized internally. Despite several SC management models, this paper emphasizes comparing the lean-SC model versus agile-SC model because they are two major management styles that the industry implements the most (Qrunfleh and Tarafdar, 2013).

\subsection{Lean-SC Management Model}

Lean industrial management was firstly introduced by the Toyota Production System, an approach concentrating on the constant operations to eliminate every kind of wastes that do not enhance profit to their goods (Lai et al., 2020). Lai et al. (2020) reported that the success in implementing lean management depends on three aspects, i.e., organizational culture, management, and knowledge. Dealing with 
manufacturers and suppliers has been historically problematic because of the shortage of capital/resources and a low-cost workforce. The situation gave companies a necessity to implement lean-SC management, in which improved stock management is supported. The lean-SC strategy emphasizes reducing cost and eliminating waste. Since it was promoted in 1990s, lean-SC management has been recognized as the supporter for supplier development, problem-solving, employee engagement, and continuous improvement (Backstrand and Powell, 2021).

The lean- SC strategies include reducing non-valueadded processes and improving value-added operations $(\mathrm{Wu}$ and Wee, 2009), in which leanness is applied up the chain (Mason-Jones et al., 2000). Also, the lean-SC concept is related to the just-in-time concept $(\mathrm{Wu}, 2009)$ and zero inventory management (Fan et al., 2007). Just-in-time is a concept created by a Japanese conglomerate to lower production lead times through improved stock management. Cabral et al. (2012) argue that although an improved stock management strategy requires lower inventory costs, responses to order fulfilment rates and urgent distributions are principal for applying this approach successfully. Lower business-stock often indicates lower resilience, and this characteristic is usually unwanted in the clothing business, in which customers' demands are frequently unstable, and fashion trends are determined by seasonality.

The fast-fashion industry is one of the primary recipients of the lean-SC system in the clothing retail business (Allwood et al., 2006). Nevertheless, the lean-SC model implemented by fast-fashion companies considerably lessen SC transparency. It is a particular problem today, as the hope of enforcing and maintaining ethical procurement and production through the SC is beyond doubt. Pedersen and Andersen (2013) argue that firms usually see ethical resourcing as a competitive advantage because it increases international trade, while a dearth of transparency can cause ecological corruption and human rights neglect. Plambeck (2012) suggests that the lack of transparency can cause legal liability and a negative brand image.

Numerous studies have been conducted on lean-SC efficiency, and it is often discovered that companies need to improve their primary operations before contracting with a supplier. For instance, Cram et al. (2015) found that in a Croatian factory implementing the Lean-SC management model, delays in the supply delivery were not caused by suppliers' assumed ineffectiveness but by ineffective communication methods between the company and producers. The absence of effective communication between business partners resulted in a bullwhip effect in which inaccurate information between partners prolonged lead times, caused inefficient inventory management, and increase a sense of conflict between partners. Based on Ancarani et al. (2015), a psychological void is frequently implied as a trigger for enlarged costs associated with such complex SC management in terms of communication effectiveness. The application of advanced technologies, i.e., blockchain, information and communication technology (ICT), and enterprise resource planning (ERP), are needed to alleviate the issue (Ancarani et al., 2015).

Lean-SC management does not immediately improve business competitiveness in industries. If a ripple effect often occurs, keeping inventory low can cause deficits in trades and demands (Tang, 2006). The inflexible features of
lean-SC management signify unanticipated changes, including the Coronavirus pandemic, leading to severe disturbances in the SCs. A steady and conventional clothing company delivered favorable settings for applying lean-SC strategy; however, the latest clothing trends have shifted from yearly popularity of two seasons to adapting to quickly varying trends. Companies and sellers need faster inventory refilling to follow the fashion trend, signifying possible SCs or more prolonged lead-times disturbances, leading to market-share reduction.

\subsection{Agile-SC Management}

Advances in the social-media and Internet-based marketings affected the development of a "See Now Buy Now" concept in the clothing business (Robinson and Hsieh, 2016), causing greater instability in customer demands preferences. Based on Christopher (2000), it initiated the acceptance and application of a more agile and flexible SC management to guarantee that companies are competent in dealing with uncertainty. Pearson et al. (2010) argued that the clothing industry's development signified the market situation has shifted into pilot briefer life cycle goods, high variation of goods, differentiation of goods as a competitive advantage, volatile demands, and small production capacity; with high turnovers. This growing economic scale and product diversity necessitated companies' responsiveness to customer demand, promoting agile-SC management (Fan et al., 2007). Cabral et al. (2012) argue that agile-SC management is similar to lean-SC in emphasizing the quick response to demand fulfillment and urgent delivery. Nevertheless, the two are different in how agile-SC management is implemented down the chain (Mason-Jones et al., 2000), incorporating SC and business partners as the area of concern. By adopting agile-SC management, firms employ developed communication methods and relation formations with broader information accessibility between parties in the SCs to increase responsiveness to changes (Bottani,2009).

A company's shift from a cost-cutting approach to a value-creation strategy increased its marketplace position and provided a high competitive advantage. It resulted in a broader implementation of the business's agile-SC model than the lean-SC style (Ellram et al., 2013). Moreover, the agility improved information sharing; thus, it enhanced SC management and coordination with mitigated disturbances and shortened lead times (McLaren et al., 2002). In the fastfashion companies, agile-SC management can enhance differentiated product collection, and in the high-end sector, brands like Gucci and Burberry can also establish better product quality management, maintaining their statuses for legacy and fame. Those companies pay immense attention to $\mathrm{R} \& \mathrm{D}$ to maintain a competitive advantage by purchasing creative designs and materials that allow them to effortlessly and quickly transition to the production phase if the company can hold effective SC management (Fratocchietal., 2015). Besides, enhanced communication and coordination in the SC systems increase transparency where firms can develop improved relations with their business partners and promote moral and ecologically-friendly operations, thus alleviating reputation risks. The concept of a complex adaptive system (CAS) can be applied to supervise suppliers and intermediary networks to enhance the decision-making 
process (Pearson et al., 2010). It may be expensive in the short run; however, agile-SC management can intensify competition among supply partners in the long run because firms will have richer information about the supplier operations, providing possible cost reductions in management, production, and materials.

Carvalho et al. (2011) argue that a flexible/agile-SC management system's main weakness is enlarged inventory amounts, which may raise holding costs and stockmanagement budgets and increase the material obsoleteness risk. Agile-SC management relies on providing the flexibility to modify SC partners to fit the conditions and circumstances. The model also involves maintaining high inventories in the SCs, resulting in significant deficits and lower flexibility in its operations (Cabral et al., 2012). Firms looking to implement flexible-SC management need to determine the level of stock-capacity that will be best for their business practices, considering a tolerable rise in management and holding costs. Other approaches applying flexible-SC management that many firms implement are: (i) developing partnerships with different enterprises to distribute SC operations, and (ii) promoting collaborations among various company segments such as those found in high-end clothing corporations.

Pujawan \& Bah (2021) argue that flexible agile-SC needs to arrange additional resources to control instabilities, provide swiftness when it is required, and remain economically viable under declining demands. Nonetheless, the unpredictability caused by the epidemic is supposed to last for an extensive time period, an SC must not be conceived to either be agile or efficient, but integrating the both will be necessary.

\section{IMPLICATIONS OF CORONAVIRUS FOR SUPPLY CHAIN RISK MANAGEMENT}

\subsection{Supply Chain Disturbances}

Specific disturbance risks such as environmental catastrophes, human-made disasters, strikes, and legal disputes vigorously and immediately influence SCs. Dolgui et al. (2017) report that without sufficient 'safeguards,' disturbances in an SC stage can spread down the chain, resulting in a ripple effect in which SC operation is growingly at risk with every spread of the ripple. SCs with short-lead times will notice disturbances spread downstream quicker because they usually have no 'safeguards' (Haren and Simchi-Levi, 2020).

Ivanov (2020) argues that highly internationalized companies are particularly disposed to pandemic disturbances. According to Teodoro and Rodriguez (2020), in the first quarter of 2020, global trade values decreased by 3 percent, with more than 90 percent of Fortune- 100 companies informing SC disruptions associated with the Coronavirus outbreak.

Ivanov (2020) suggests that the following aspects typify epidemics: (i) unexpected long-run disturbance, (ii) the ripple effect spreading disturbances all over the SC, and (iii) simultaneous disturbances in logistics systems and supply and demand. Geographic space limits the specific disturbance risks; nevertheless, pandemics that are initially small can spread quickly through massive geographic areas because of the current internationalized community.

Ivanov (2020) suggests that SC elements, formerly regarded as self-reliant, probably will no longer be. In case a company applies a dual-sourcing strategy in which two supply partners are localized in immediate geographical areas, both supply partners probably can not meet demands when a lockdown restriction happens. The non-vital characteristic of the clothing products makes it particularly vulnerable to lockdown policies. Moreover, when pandemics disperse in a non-simultaneous manner and nations have different handling methods, an exclusive aspect in pandemic disturbances can be observed: distinct elements of the SC will face different grades of disturbances at different times, either as an immediate consequence of regional lockdown or from a ripple effect down the chain. According to the BBC (2020), although the Coronavirus lockdown in China started in January 2020, most nations in Europe (except Italy) did not apply lockdowns till March. Also, the different epidemiological reactions and contagion levels among different nations influence SCs. In June, SC in Africa faces extensively fewer disturbances than in Southeast Asia because of lesser contagion levels (BBC, 2020).

Based on Teodoro and Rodriguez (2020), the clothing and textile companies have been highly dependent on emerging markets for lower-cost procurement and production and are especially vulnerable to the disturbances mentioned above. They also report that China's increasing labor costs in the last ten years have shifted some manufacturing locations to other nations, i.e., Bangladesh, Pakistan, India, and Vietnam. However, China still plays an essential role in the clothing SCs, serving as an essential input supplier, producers of luxury products, and customers. Figure 1 shows the countries that are the leading exports in global clothing industry, where China ranks number one with market share value of $31 \%$ (Statista, 2021). Globally, the clothing industry remains highly reliant on Chinese factories; for instance, Aung and Paul (2020) report that China supplies 90 percent of woven fabrics/textiles in Myanmar's clothing industry and 70 percent of Bangladesh's. Those SCs were momentarily at risk as China applied lockdown in early 2020.

Similarly, it emphasizes the characteristics of the clothing SCs that are geographically complex and interconnected, making them vulnerable to pandemic disturbances and their resulting ripple effect. China's lockdown directly affected the country's international trade (Araz et al., 2020); thus, postponements spread down the SCs.

On the contrary, when industries in China started to reopen their brick-and-mortar stores and resume manufacturing activities, the continuing lockdowns in American, European, and Southeast Asian countries kept on disrupting Chinese manufacturing abilities. Those disruptions are a specific problem in the clothing business because products usually have short life cycles due to seasonality. Relatively, based on Aung and Paul (2020), in the fast-fashion industry, where products are mostly retailed in two-to-four-weeks rounds, SC disturbances display a higher risk. Hence, the pressure to cut costs and improve SC effectiveness has made clothing SCs highly vulnerable to pandemic disturbances. 


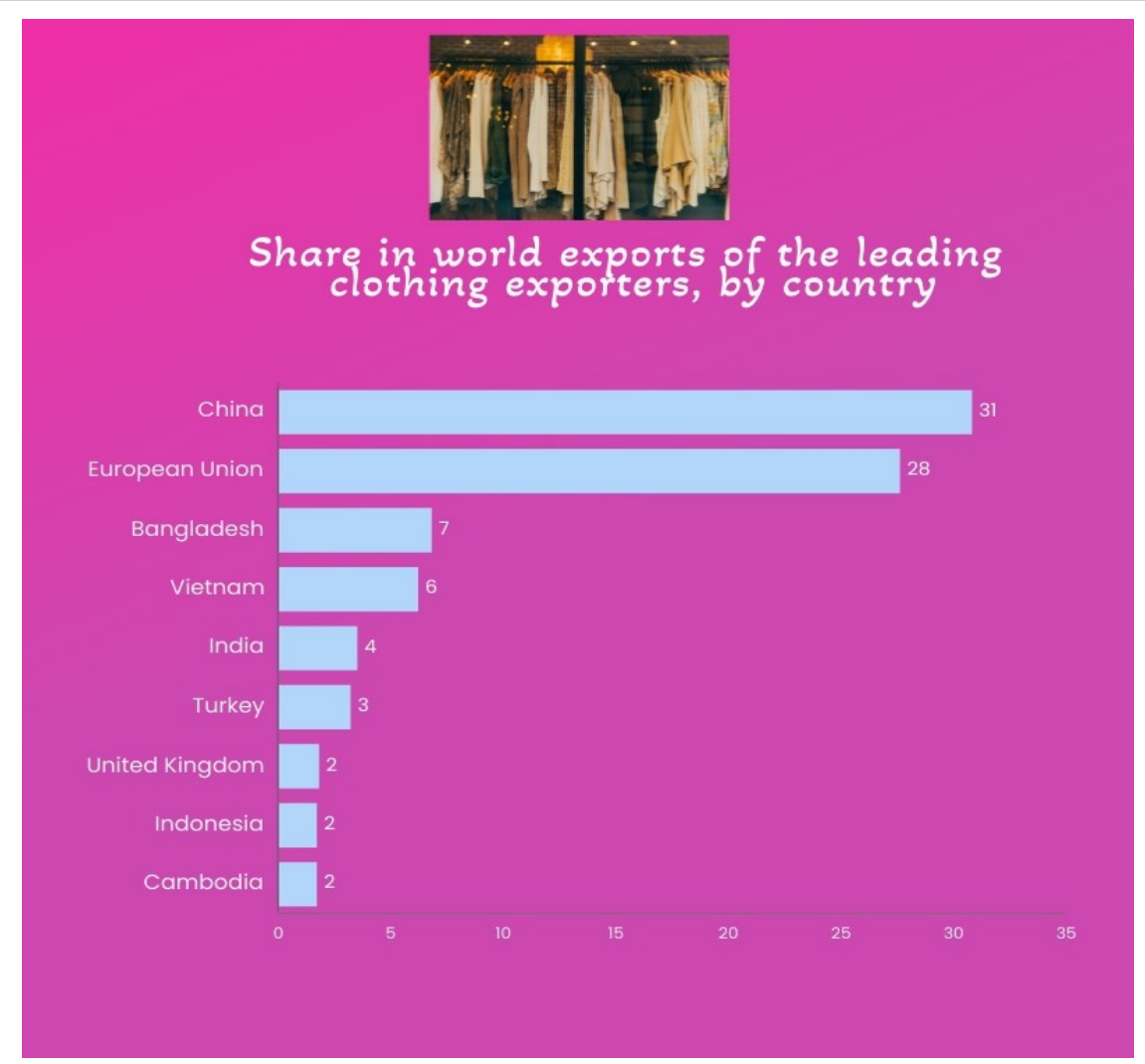

Figure 1 Share (\%) in world exports of the leading clothing exporters (source: Statista, 2021)

\subsection{Demand Disturbances}

It has also been observed that the Coronavirus causes immediate disturbances in demand and supply, with changes in customer demand and resultant order cancellation having a long-term impact on the international SCs (Ivanov, 2020; Teodoro and Rodriguez, 2020). The closings of stores and customers' lockdowns have caused a significant shift in consumers' demands for clothes. For example, customer expenditure in Denmark experienced an overall decline of 27 percent in the 7th week after the lockdown (Andersen et al., 2020). The financial slump and unemployment indicate that customer expenditure changed its direction mainly to vital commodities such as foods and health products. H\&M suffered a sales drop of nearly 60 percent between March 1 and May 6, as 80 percent of H\&M's stores remain closed globally (Nazir, 2020). Although most shops in China had resumed at the end of March, more than 3,700 shops in 39 global marketplaces were still momentarily closed (Inditex, 2020). As of September 9, more than 31 million garment workers in the Asia Pacific region were still affected by factory closure, whereas over 60 percent of the world's clothing exports presently come from the Asia-Pacific region (Lu, 2020).

Pearson et al. (2010) suggest that the strategy of shortlead time implemented in the fast-fashion SCs depends on expectations about customers' demands. When lockdown and monetary downturn situations lessen the need for nonvital products, numerous companies have been cancelling orders and raising the 'inevitable accident' stipulation (Teodoro and Rodriguez, 2020). Once more, a situation in which pandemics can endanger the elements of the SCs is observed.

\section{LIMIT ISSUES: MANAGING RISKS, COSTS, AND RESILIENCE POST-CORONAVIRUS}

Coronavirus has exposed a new series of SC risks that multinational companies must take into account. By depending on the zero-inventory approach and Just-in-Time management, the lean SCs are vulnerable to a pandemic disturbance. Meanwhile, developing the agile system is a costly and unfeasible practice for a company to fully repair its SC to control risk occurrences like the Coronavirus pandemic. Hence, this part discovers various tactics of various costs that firms can apply to alleviate supply and demand disturbances caused by the Coronavirus in the short run, medium run, and long run.

\subsection{Handling SC Disturbances}

ecause pandemics have the potentials to disturb input procurement, leaders need to adjust the resourcing mix to differentiate risks more effectively. Implementing a dual sourcing strategy in which two supply partners are in the same location creates a more significant lockdown disturbance. Likewise, companies with supplier groups in different geographical areas remain potentially unprotected from SC disturbances if their products rely on resources from numerous supply partners because a solitary interruption can create a resultant ripple effect. As Gyarmathy et al. (2020) proposes that the higher the dependability on international sourcing, the higher the likelihood of failing flexibility and agility. Leaders should resolve which commodities are specifically vulnerable to single-sourcing or single-site dependencies and work towards developing suitable risk management tactics. The short-term strategy may involve 
inventory reallocation to various areas or decreasing reliance on commodities at disturbance risk. For instance, ASOS, a digital fast-fashion firm, worked with supply partners to change manufacture to match the new demands for sportswear and casualwear (ASOS, 2020). A medium-run strategy can include building 'safeguards' to lessen the ripple effect as a single supplier is at risk. It can be applied in the following methods: (i) firms can set up a business-stock 'safeguard' of critical elements and goods and, (ii) companies can make a time 'safeguard' by postponing the manufacture of products when demand is uncertain.

Companies are encouraged to maintain their vital suppliers who are suffering financially as replacing them can be problematic and costly. For instance, if Italian contract manufacturers (usually companies which are family-run and small scale) endure bankruptcy, work experience over the years will be gone, and the high-end clothing SCs will be at risk (Achille and Zipser, 2020). Many clothing companies in emerging nations strive to tackle lesser volume, lower demand, and order cancellation caused by the Coronavirus (Teodoro and Rodriguez, 2020). Companies should support their partners on SC, purpose to long-run strategies of SC unity, business stability, and societal sustainability; thus, companies need to: (i) consider those supports to revitalize their supply partners and (ii) determine where to apply those supports for maximizing support benefits (STAR, 2020).

Based on corporate social responsibility (CSR) and an economic viewpoint, global clothing companies need to operate with business partners to make sure manufacturing resources and industrial units comply with the latest socialdistancing rule and public health conditions. Although social-distancing restriction seems to result in higher budgets for inputs and smaller company outputs, the risk of complete industrial unit closure will be minimalized. Cohn (2020) suggests that after a worker has confirmed positive for Coronavirus, companies must work rapidly and resolve if their workers can continue to work in the office or need to work from home. According to The Centers for Disease Control, a minimum of two-weeks of isolation is necessary for workers who have been in 'close interaction' (within six feet for an extended time) with the affected person (Cohn, 2020). For instance, the company should determine its workers as close interactions and instruct them to work from home to quarantine themselves. For factories where the societal-distancing rule is respected, they probably should only quarantine a few workers. Whereas factories that do not follow social-distancing restrictions should quarantine all employees, causing a total closure of the factories. Companies also need to build procedures that allow them to act swiftly after contagion to lessen the next dispersion risk.

\subsection{Handling Demand Disturbances}

As already discussed, the demand for clothing items has experienced a drastic decline due to the Coronavirus effects. Achille and Zipser (2020) report that purchases of luxury goods are 70 percent less for the 2020 spring season than 2019. Although the customers' request is ready to resume as the lockdown policies are loosened, it is unidentified to what degree it will resume. As more people work from home, it can be predicted that the characteristic of demand for particular clothing goods will transform. Besides, the prospect and level of the 'second wave' of Coronavirus infection remain mostly unidentified. Thus, firms must think about some practical approaches to handle further demand disturbances.

The Kering Group moved product supply from China to the less disrupted countries in the first quarter of 2020. Leonard (2020) reports that the company's SC management strategy is refilling products' inventory when they are out of stock rather than sending the entire product supplies to those areas at every clothing season. It has given the company great flexibility in reacting to the changing demand because commodities did not become "stuck" in China throughout the early pandemic. In June 2020, as the Chinese economy reopens, the company can see to refill its Chinese-product stock level. Therefore, clothing firms need to replenish the inventory during the clothing season in response to real demands, rather than at the beginning of the seasons based on forecasted demands. This SC-management tactic produces higher agility in reacting to possible demand disturbances.

In comparison, companies with a resilient online existence need to maintain transactions following the physical stores' closure. ASOS, an Internet-based seller, has announced the cancellation of below 1 percent of its 2020 Spring-Summer sales (ASOS, 2020). The internet-based product offering is also more effortless to renew than the brick-and-mortar offering; thus, firms with Internet-based stores can quickly modify their product offerings to match the latest demand situations.

In the long run, every clothing company must strive to increase their existence on websites. High-end product manufacturers need to pay special attention to developing digital involvement since their customers are familiar with quality in-store facilities and expect similar services on websites (Achille and Zipser, 2020). It can be completed inhouse by capitalizing in a web-based storefront or by partnerships with leading Internet-based marketers. Besides, companies can apply for current advances in augmentedreality technologies to build online display-room and fittingroom. According to Sheldon (2019), in 2018, GAP launched the DressingRoom, i.e., an app that lets customers try on clothes digitally. Parker (n.d) also has incorporated this virtual try-on feature into companies' mobile apps. Therefore, firms must find creative methods to expand their digital performance in the post-Coronavirus industry situation to alleviate demand disturbances by maximizing customer experiences.

Studies related to the Coronavirus and its impacts on global SCs remains comparatively rare. Moreover, the longrun effect of the Coronavirus on supply and demand still needs further investigation. As firms announce quarterly revenue and reports, and as more news related to alleviating Coronavirus spread emerges, scholars and business managers need to see to reexamine SC risk management and SC tactics.

Studies can be conducted to investigate the effect of pandemic disturbances using a statistical method, delivering more convincing perceptions about the degree of disturbances firms might have faced. The study mostly abandoned the corporate social responsibility (CSR) element of the international SC management. As mentioned in Part 5, lots of small-scale and family-run manufacturers/suppliers are coping with bankruptcy. From a CSR viewpoint, multinational companies need to support those business 
partners and guarantee that workplace situations abroad are secure from the Coronavirus. Moreover, there is a rising problem: whether the Coronavirus pandemic will witness a 'second-wave' of global spread, and how it will influence SCs and customer demands in the future. Lastly, the effects of multidimensional pressures provoked by arguments about the Coronavirus sources on SC systems should be tackled to inspect the impact of politics on the SC management and business operation. In general, as the latest news about Coronavirus arises, scholars and corporate managers might need to reassess SC management approaches.

\section{CONCLUSIONS}

After the industrial development of today's leading markets, studies on the SC management model principally emphasized handling growingly demanding customers by shifting manufacture to countries with low labor cost, mainly through lean-SC management.

More current studies identify a necessity to select different management models to solve critical issues that challenge business activities. This paper's literature review exemplified the necessity for future studies into the significance of agility in SC management, an aspect often neglected due to concentrating on purchaser-supplier relations. It is particularly crucial given the idea that the Coronavirus pandemic has driven far-reaching SC disturbances in many countries through various time points

Earlier studies have provided essential findings that reinforce or contradict the complex-SC system. Although the advantages of diversification and flexibility provided by complex models help alleviate risk, they result in reduced economies of scale if companies diversify excessively and cause higher vulnerability to the resonance of disturbance impacts with the whole SC. This paper clarifies that the ideal SC management model highly relies on company-specific attributes.

Studies about the benefits and pitfalls of lean-SC versus agile-SC model also clarify this idea. Fast-fashion firms have primarily implemented lean-SC management with its focus on minimizing costs and wastes. Nevertheless, it substantially lessens transparency in SCs, which has previously caused a far-reaching and highly exposed reaction for numerous firms. Besides, the rigidity in lean-SC management requires that undesirable shocks can trigger radical disturbances to the SCs. Agile-SC management overcomes the rigidity by considering intrinsic uncertainties.

Via more excellent communication methods and a higher focus on the practical information exchange between purchasers and suppliers, alliances are developed to increase the operational situation's responsiveness. Therefore, the emphasis is moved from reducing costs in lean-SC management to creating values in agile-SC management. The second is restricted by higher inventory necessities, which involves more massive inventory and management costs.

Current studies on SC management has not yet explained how the Coronavirus has affected SCs and impacted SC-management theories. The Coronavirus pandemic has emphasized risks in global and regional SCs as centralized sourcing is highly vulnerable to the risk of pandemic disturbances. Global SCs, on the other hand, have viewed the closings of various $\mathrm{SC}$ elements at various time points as nations differ in when the outbreak disperses and their ability to control it. It has been particularly challenging in the clothing business because of the product seasonality and SC's interrelated characteristic. Moreover, the clothing business has viewed demand disturbances because of the extensive lockdown restrictions and economic recession, which causes reduced consumption. The risks in SC management that have appeared because of the Coronavirus pandemic emphasize the necessity for subsequent investigations and direction on developing agility to alleviate the pandemic-induced risks.

To integrate higher flexibility into SCs, firms should implement risk-management tactics that consider sourcing reliances and establish "safeguards" to mitigate the effects of disturbances. Besides, firms need to help their major supply partners cope with bankruptcy and guarantee socialdistancing rules are being followed to keep long-run relationship advantages. Inventory management approaches based on real demand instead of forecasted demand can result in higher flexibility for some firms, and investing in digital customer experiences should be done to handle demand disturbances and increase trades.

Future investigations are required to expand knowledge about SC-risk management, as more evidence on the impacts of the outbreak on global trade is issued. This paper classified main research fields as follows: (i) quantitative analysis of the SC disturbances driven by the Coronavirus epidemic, (ii) company's initiatives to support financially disadvantaged supply-partners, (iii) the effects of a possible second wave of contagions on SC management and consumer's buying behaviors, (iv) the impact of legal disputes on global trade and SC management. In general, the study presents several critical challenges that have been triggered by the Coronavirus epidemic where scientists and managers should reconsider clothing SC management going forwards.

\section{CONFLICT OF INTEREST}

The scientists affirm no conflict of interest.

\section{REFERENCES}

Achille, A., and Zipser, D. (2020). A perspective for the luxury-goods industry during - and afterCoronavirus, McKinsey \& Company, 1 April, viewed 29 March 2021,

$<$ https://www.mckinsey.com/industries/retail/ourinsights/a-perspective-for-the-luxury-goods-industryduring-and-after-coronavirus $>$

Allwood, J.M., Laursen, S.E., De Rodriguez, M. and Bocken, N.M.P. (2006), Well dressed? The present and future sustainability of clothing and textiles in the United Kingdom, Institute for Manufacturing, University of Cambridge, London.

Ancarani, A., Di Mauro, C., Fratocchi, L., Orzes, G. and Sartor, M. (2015). Before reshoring: A duration analysis of foreign manufacturing ventures. International Journal of Production Economics 169, pp.141-155.

Andersen, A. L., Hansen, E. T., Johannesen, N. and Sheridan, A. (2020). Consumer responses to the COVID-19 crisis: Evidence from bank account transaction data. Covid Economics 7, pp.88-114. 
Araz, O. M., Choi, T. M., Olson, D. and Salman, F. S. (2020). Data analytics for operational risk management. Decision Sciences.

Armani, A. M., Hurt, D. E., Hwang, D., McCarthy, M. C. and Scholtz, A. (2020). Low-tech solutions for the COVID-19 supply chain crisis. Nature Reviews Materials 5(6), pp.403-406.

ASOS. (2020). Working with Our Suppliers during Coronavirus: May 2020 Update. ASOS PLC [Press release].. 2 May, viewed 20 August 2020, $<$ https://www.asosplc.com/ \{\}$/$ media/Files/A/Asos$\mathrm{V} 2 /$ reports-and-presentations/working-withoursuppliers-during-Coronavirus-May-2020update.pdf $>$

Aung, T. T. and Paul, R. (2020). Asia's Garment Industry Sees Lay-Offs, Factories Closing Due to Coronavirus, 28 February, viewed 29 March 2020, $<$ https://www.reuters.com/article/china-healthtextiles/asiasgarment-industry-sees-lay-offs-factoriesclosing-due-to-coronavirus-idUSL3N2AS1OE>

Backstrand, J. and Powell, D. (2021). Enhancing Supply Chain Capabilities in an ETO Context Through Lean and Learn. Operations and Supply Chain Management: An International Journal 14 (3), pp.360-367.

BBC. (2020). Coronavirus Pandemic: Tracking global pandemic, 6 September, viewed 29 March 2021, $<$ https://www.bbc.com/news/world-51235105>

Bevilacqua, M., Ciarapica, F. E. and Marcucci, G. (2019a). Supply chain resilience research trends: A literature overview. IFAC-PapersOnLine 52 (13), pp.28212826.

Bevilacqua, M., Ciarapica, F. E., Marcucci, G. and Mazzuto, G. (2019b). Fuzzy cognitive maps approach analyzes the domino effect of factors affecting supply chain resilience: A fashion industry case study. International Journal of Production Research 58 (20), pp. 63706398.

Bottani, E. (2009). A fuzzy QFD approach to achieve agility. International Journal of Production Economics 119 (2), pp. 380-391.

Cabral, I., Grilo, A. and Cruz-Machado, V. (2012). A decision-making model for lean, agile, resilient, and green supply chain management. International Journal of Production Research 50 (17), pp. 4830-4845.

Caniato, F., Crippa, L., Pero, M., Sianesi, A. and Spina, G. (2015). Internationalization and outsourcing of operations and product development in the fashion industry. Production Planning \& Control 26 (9), pp.706-722.

Carvalho, H., Duarte, S. and Cruz Machado, V. (2011). Lean, agile, resilient, and green: divergencies and synergies. International Journal of Lean Six Sigma 2 (2), pp.151179.

Choi, T.M. (2007). Pre-season stocking and pricing decisions for fashion retailers with multiple information updating. International Journal of Production Economics 106 (1), pp.146-170. doi:10.1016/j.ijpe.2006.05.009

Christopher, M. (2000). The agile supply chain. Industrial Marketing Management 29 (1), pp.37-44. doi:10.1016/s0019-8501(99)00110-8

Cohn, A. (2020). Your employee tested positive for Coronavirus. What do you do? Harvard Business
Review, 30 March, viewed 20 August 2020, $<$ https://hbr.org/2020/03/your-employee-testedpositive-for-covid-19-what-do-you-do $>$

Di Gregorio, D., Musteen, M. and Thomas, D. E. (2008). Offshore outsourcing as a source of international competitiveness for SMEs. Journal of International Business Studies, $40 \quad$ (6), pp.969-988. doi:10.1057/jibs. 2008.90

Dolgui, A., Ivanov, D. and Sokolov, B. (2017). Ripple effect in the supply chain: analysis and recent literature. International Journal of Production Research 56 (1-2), pp.414-430. doi:10.1080/00207543.2017.1387680

Ellram, L. M., Tate, W. L. and Petersen, K. J. (2013). Offshoring and reshoring: An update on the manufacturing location decision. Journal of Supply Chain Management 49 (2), 14-22. doi:10.1111/jscm.12019

Ernst and Young. (2020). Nearly $80 \%$ of board members felt unprepared for a major risk even like Coronavirus: EY survey, 20 April, viewed 21 July 2020, $<$ https:/www.ey.com/en_us/news/2020/04/nearly-80percent-ofboard-members-felt-unprepared-for-amajor-risk-event-like-Coronavirus-ey-survey>

Fan, Q., Xu, X. and Gong, Z. (2007). Research on Lean, Agile, and Leagile Supply Chain. 2007 International Conference on Wireless Communications, Networking and Mobile Computing, pp.1-15. doi:10.1109/wicom.2007.1201

Fisher, M. L. (1997). What is the right supply chain for your product?. Harvard business review 75, pp.105-117.

Fratocchi, L., Ancarani, A., Barbieri, P., Di Mauro, C., Nassimbeni, G., Sartor, M., ... Zanoni, A. (2015). Manufacturing back-reshoring as a nonlinear internationalization process. The Future of Global Organizing, pp.365-403. doi:10.1108/s1745886220150000010011

Gligor, D. M., Esmark, C. L. and Holcomb, M. C. (2015). Performance outcomes of supply chain agility: when should you be agile?. Journal of Operations Management 33, pp.71-82.

Graafland, J. J. (2002). Sourcing ethics in the textile sector: The case of C\&A. Business Ethics: A European Review 11 (3), pp.282-294.

Gyarmathy, A., Peszynski, K. and Young, L. (2020). Theoretical framework for a local, agile supply chain to create innovative product closer to end-user: onshoreoffshore debate. Operations and Supply Chain Management: An International Journal, pp.108-122. https://doi.org/10.31387/oscm0410256

Haren, P. and Simchi-Levi, D. (2020). How Coronavirus Could Impact the Global Supply Chain by Mid-March. Harvard Business Review, 1 February, viewed 29 March 2020 ,

$<$ https://hbr.org/2020/02/howcoronavirus-couldimpact-the-global-supply-chain-by-midmarch\#comment-section>

Inditex. (2020). FY2019 Results, 2 April, viewed 21 July 2020,. Retrieved from https://www.inditex.com/documents/10279/625777/Fu 11+year+2019+Results.pdf/e1ba8b1e-8788-05fa-8ec5$76 \mathrm{~b} 4641 \mathrm{c} 27 \mathrm{bb}$.

Ivanov, D. (2020). Predicting the impacts of epidemic outbreaks on global supply chains: A simulation-based 
analysis on the coronavirus outbreak (COVID19/SARS-CoV-2) case. Transportation Research Part E: Logistics and Transportation Review 136, pp.10191022. doi:10.1016/j.tre.2020.101922

Ivanov, D. and Das, A. (2020). Coronavirus (COVID19/SARS-CoV-2) and supply chain resilience: A research note. International Journal of Integrated Supply Management 13(1), p.90. doi:10.1504/ijism.2020.107780

Ivanov, D. and Dolgui, A. (2019). Low-Certainty-Need (LCN) supply chains: A new perspective in managing disruption risks and resilience. International Journal of Production Research 57(15-16), pp.5119-5136. doi:10.1080/00207543.2018.1521025

Ivanov, D. and Dolgui, A. (2020). Viability of intertwined supply networks: extending the supply chain resilience angles towards survivability. A position paper motivated by the COVID-19 outbreak. International Journal of Production Research 58(10), pp.2904-2915. doi:10.1080/00207543.2020.1750727

Ivanov, D., Dolgui, A. and Sokolov, B. (2018). The impact of digital technology and Industry 4.0 on the ripple effect and supply chain risk analytics. International Journal of Production Research 57(3), pp.829-846. doi:10.1080/00207543.2018.1488086

Kim, B. (2013). Competitive priorities and supply chain strategy in the fashion industry. Qualitative Market Research: An International Journal 16(2), pp.214-242. doi:10.1108/13522751311317602

Kram, M., Tošanović, N. and Hegedić, M. (2015). Kaizen approach to supply chain management: First step for transforming the supply chain into the lean supply chain. ANNALS of Faculty Engineering HunedoaraInternational Journal of Engineering 13 (1), pp.161164.

Lai, E. T. H., Yun, F. N. J., Arokiam, I. C. and Joo, J. H. A. (2020). Barriers affecting successful lean implementation in singapore's shipbuilding industry: A case study. Operations and Supply Chain Management: An International Journal, pp.166-175. https://doi.org/10.31387/oscm0410260

Lee, H. L. (2002). Aligning supply chain strategies with product uncertainties. California management review 44(3), pp. 105-119.

Leonard, M. (2020). Gucci shuffles inventory to manage coronavirus impact. Supply Chain Dive, 14 February, viewed 21 July 2020, $<$ https://www.supplychaindive.com/news/guccishuffles-inventory-to-minimizecoronavirusimpact/572267/>

Lu, S. (2020). New ILO report: The supply chain ripple effect- How COVID-19 affects garment workers and factories in Asia and the Pacific, 21 October, viewed 29 March

$<$ https://shenglufashion.com/2020/10/21/new-iloreport-the-supply-chain-ripple-effect-how-covid-19is-affecting-garment-workers-and-factories-in-asiaand-the-pacific/>

Martino, G., Fera, M., Iannone, R., Sarno, D. and Miranda, S. (2015). Risk identification map for a fashion retail supply chain. Proceedings of Summer School "Francesco Turco," Senigallia, Italy, pp. 208-216.
Mason-Jones, R., Naylor, B. and Towill, D. R. (2000). Engineering the leagile supply chain. International Journal of Agile Management Systems 2 (1), pp.54-61. doi:10.1108/14654650010312606

McLaren, R., Tyler, D. J. and Jones, R. M. (2002). Parade exploiting the strengths of the "Made in Britain" supply chain. Journal of Fashion Marketing and Management: An International Journal, 6 (1), pp. 35-43. doi:10.1108/13612020210422446

Mehrjoo, M. and Pasek, Z. J. (2015). Risk assessment for the supply chain of fast fashion apparel industry: A system dynamics framework. International Journal of Production Research 54(1), pp.28-48. doi:10.1080/00207543.2014.997405

Mustafid, N. A., Karimariza, S. A. and Jie, F. (2018). Supply chain agility information systems with critical factors for fashion industry competitiveness. International Journal of Agile Systems and Management 11(1), p.1. doi:10.1504/ijasm.2018.091352

Nagurney, A., Yu, M. and Floden, J. (2015). Fashion supply chain network competition with ecolabeling. Sustainable Fashion Supply Chain Management, pp.61-84. doi:10.1007/978-3-319-12703-3_4

Naylor, J. B., Naim, M. M. and Berry, D. (1999). Leagility: Integrating the lean and agile manufacturing paradigms in the total supply chain. International Journal of Production Economics 62 (1-2), pp.107-118. doi:10.1016/s0925-5273(98)00223-0

Nazir, S. (2020). 60\% drop in H\&M sales as lockdown affects business, 1 May, viewed 21 July 2020, $<$ https://www.retailgazette.co.uk/blog/2020/05/60drop-in-hm-sales-as-lockdown-affects-business/>

Parker, W. (n.d). It is all in the app, viewed 29 March 2020, $<$ http://www.warbyparker.com/app>

Pearson, M., Masson, R. and Swain, A. (2010). Process control in an agile supply chain network. International Journal of Production Economics 128(1), pp.22-30. doi:10.1016/j.ijpe.2010.01.027

Pedersen, E. R. G. and Andersen, K. R. (2014). The SocioLog. $d x$ experience: A global expert study on sustainable fashion. Copenhagen: Copenhagen Business School Centre for Corporate Social Responsibility (cbsCSR).

Plambeck, E. L. (2012). Reducing greenhouse gas emissions through operations and supply chain management. Energy Economics 34, pp.564-574. doi:10.1016/j.eneco.2012.08.031

Pujawan, I.N. and Bah, A.U. (2021). Supply chains under COVID-19 disruptions: Literature review and research agenda. Supply Chain Forum: An International Journal, pp.1-15. DOI:https: //doi.org/10.1080/16258312.2021.1932568

Qrunfleh, S. and Tarafdar, M. (2013). Lean and agile supply chain strategies and supply chain responsiveness: The role of strategic supplier partnership and postponement. Supply Chain Management 18 (6), pp.571-582. doi:10.1108/SCM-01-2013-0015

Robinson, P. K. and Hsieh, L. (2016). Reshoring: A strategic renewal of luxury clothing supply chains. Operations Management Research 9 (3-4), pp.89-101. doi:10.1007/s12063-016-0116-x

Sarkar, S. and Kumar, S. (2015). A behavioral experiment on inventory management with supply chain disruption. 
International Journal of Production Economics 169, pp. 169-178. doi:10.1016/j.ijpe.2015.07.032

Sheldon, P. (2019). Augmented reality in retail: Virtual try before you buy. MIT Technology Review, 23 October, viewed 29 March 2021, $<$ https://www.technologyreview.com/2019/10/23/238 473/augmented-reality-in-retail-virtualtry-before-youbuy/>

Shen, B. and Chen, C. (2019). Quality management in outsourced global fashion supply chains: An exploratory case study. Production Planning \& Control 31(9), pp. 757-769. doi:10.1080/09537287.2019.1683774

Sherman, E. (2020). 94\% of the Fortune 1000 see Coronavirus supply chain disturbances: Report. New York: Fortune.

Snyder, L. and Shen, Z. M. (2019). The Bullwhip effect. Fundamentals of Supply Chain Theory, pp. 539-562. DOI: $10.1002 / 9781119584445 . c h 13$

Sreedevi, R. and Saranga, H. (2017). Uncertainty and supply chain risk: The moderating role of supply chain flexibility in risk mitigation. International Journal of Production Economics 193, pp.332-342. doi:10.1016/j.ijpe.2017.07.024

STAR. (2020). Joint statement on responsible purchasing practices amid the COVID-19 crisis [Press release], 1 April, viewed 20 August 2020, $<$ http://www.asiatex.org/ennewss/393.html>

Statista (2021). Share in world exports of the leading clothing exporters in 2019, by country. 23 November, viewed 29 March 2021, $<$ https://www.statista.com/statistics/1094515/share-ofthe-leading-global-textile-clothing-by-country/>

Sumarliah, E. (2021). Risk assessment in the Islamic clothing supply chain management using Best-Worst method. International Journal of Islamic Business Ethics (IJIBE), $6 \quad$ (1). http://dx.doi.org/10.30659/ijibe.6.1.1-26

Sumarliah, E., Li, T. and Wang, B. (2020). Hijab fashion supply chain: A theoretical framework traversing consumers' knowledge and purchase intention. MATEC Web of Conferences, 308, pp. 04004. DOI:10.1051/matecconf/202030804004

Sumarliah, E., Li, T. and Wang, B. (2021a). An examination of halal fashion supply chain management risks based on the fuzzy best-worst approach. Information Resources Management Journal 34 (4). [in press]

Sumarliah, E., Li, T., Wang, B., Moosa, A. and Sackey, I. (2021b). The Impact of customer halal supply chain knowledge on customer halal fashion purchase intention. Information Resources Management Journal 34 (3). DOI: https://doi.org/10.4018/irmj.2021070105

Tang, C. S. (2006). Perspectives in supply chain risk management. International Journal of Production Economics $103 \quad$ (2), pp.451-488. doi:10.1016/j.ijpe.2005.12.006

Teodoro, A. and Rodriguez, L. (2020). Textile and Garment Supply Chains in Times of COVID-19: Challenges for Developing Countries. UNCTAD Transport and Trade Facilitation Newsletter N॰86. 29 May, viewed 21 July 2020 ,

$<$ https://unctad.org/en/pages/newsdetails.aspx?Origina lVersionID $=2380>$

Westervelt, A. (2012). Target, Nike, Levi's Join Forces on Sustainable Clothing. Forbes, 26 July, viewed 20 August 2020, $<$ http://www.forbes.com/sites/amywestervelt/2012/07/ 26/target-nike-levis-join-forces-onsustainableclothing/>

WHO-World Heath Organization (2021). Weekly epidemiological update on COVID-19. 24 August, viewed 29 August 2021, $<$ https://www.who.int/publications/m/item/weeklyepidemiological-update-on-covid-19---24-august2021>

$\mathrm{Wu}, \mathrm{H}$. (2009). The lean manufacture research in the environment of the supply chain of modern industrial engineering. 2009 16th International Conference on Industrial Engineering and Engineering Management, pp. 297-300. doi:10.1109/icieem.2009.5344586

$\mathrm{Wu}$, S. and Wee, H. M. (2009). How lean supply chain affects product cost and quality - A case study of the ford motor company. 2009 6th International Conference on Service Systems and Service Management, pp. 271-276. doi:10.1109/icsssm.2009.5174890

Zhou, F., Yu, T., Du, R., Fan, G., Liu, Y., Liu, Z., ... \& Guan, L. (2020a). Clinical course and risk factors for mortality of adult inpatients with COVID-19 in Wuhan, China: A retrospective cohort study. The Lancet, 28 March, viewed 21 July 2020, $<$ https://pubmed.ncbi.nlm.nih.gov/32171076/>

Zhou, M., Zhang, X. and Qu, J. (2020b). Coronavirus disease 2019 (COVID-19): A clinical update. Frontiers of Medicine 14 (2), pp.126-135. doi:10.1007/s11684020-0767-8

Eli Sumarliah a.k.a. Elie Molly is a doctoral researcher at the School of Economics and Management, University of Science and Technology Beijing, Beijing, P.R. China. She has published numerous research articles in reputable international journals, including the International Journal of Information Systems and Supply Chain Management, Information Resources Management Journal, Journal of Islamic Marketing, Research Journal of Textile and Apparel, etc. She also has published an article in the 8th International Conference of Transportation and Traffic Engineering (Auckland, New Zealand). Her interest areas include Supply Chain Management, Information Management, E-commerce, and Consumer Behaviour.

Kamila Usmanova is a doctoral researcher at the School of Economics and Management, University of Science and Technology Beijing, Beijing, P.R. China. She has published the conference article in the 3rd International Conference on Management Engineering, Software Engineering and Service Sciences (Wuhan, P.R. China) and the journal articles in Chinese Management Studies Journal, Journal of Information, Knowledge, and Management (IJIKM), and British Food Journal. Her 
research interests: Knowledge Management, Human Resource Management, Organizational Behaviour, Creativity, Innovations, Brand Promotion, Cross-cultural Communications, and Supply Chain Management.

Fauziyah Fauziyah is a Ph.D. candidate at the School of Computer and Communication Engineering, University of Science and Technology Beijing, Beijing, P.R. China. Her research areas: Security System, Internet of Things, Artificial Intelligence, and Supply Chain Management.

Kawthar Mousa is a Ph.D. candidate at the School of Economics and Management, University of Science and Technology Beijing, Beijing, P.R. China. Her research areas include Project Management, Knowledge Man-agement, SupplyChain Management, and Consumer Behaviour. 